\title{
Levels of Satisfaction with Leisure Time in Foreign Students
}

\author{
Hakan Akdeniz ${ }^{1}$, Sinem Didem Simsek ${ }^{2}$, Onur Kavi ${ }^{2}$, Muhammet Eyup Uzuner ${ }^{1}$, Gulsah Sekban ${ }^{1}$ \\ ${ }^{1}$ Faculty of Sports Sciences, Kocaeli University, Kocaeli, Turkey \\ ${ }^{2}$ The Institute of Health Sciences, Department of Physical Education and Sports, Kocaeli University, Kocaeli, Turkey \\ Correspondence: Hakan Akdeniz, The Institute of Health Sciences, Department of Physical Education and Sports \\ Teaching, Sakarya, Turkey.
}

Received: November 15, 2017

doi:10.11114/jets.v6i3a.3162

\author{
Accepted: February 2, 2018 \\ Online Published: April 1, 2018 \\ URL: https://doi.org/10.11114/jets.v6i3a.3162
}

\begin{abstract}
The aim of this study was to investigate levels of satisfaction with leisure time in foreign students of Kocaeli University. In the collection of the data, the Leisure Satisfaction Scale (LSS) and demographic status questionnaire were used; 257 male and 103 female students participated. In the LSS scores for the separate domains, participants scored highest in Education and lowest in the Aesthetic subscale. There was no statistically significant difference in satisfaction levels between the genders, monthly income groups, and levels of academic achievement; but statistically significant differences were found between the students' faculties. Significant differences were found between faculties in the LSS scores on the Psychological subscale, and between students' monthly incomes and the Relaxation subscale on the LSS. As a result, there was a significant difference between the different faculties and students' satisfaction with leisure time on the Psychological subscale.
\end{abstract}

Keywords: leisure time, recreation, foreign student

\section{Introduction}

Technological developments advancing rapidly in recent years have brought changes to our daily lives. While this change has taken place, it has affected the use of time by individuals, introducing new concepts into our lives. Mechanization has reduced the need for human power, resulting in the concept of leisure time outside of people's working hours (Ayyildiz, 2015). Leisure time is a concept that has been defined in various ways: time outside of work, sleep and obligations; and the activities carried out in this time are also referred to as leisure time activities (Roberts, 2006; Tezcan, 1994).

It has been often observed that individuals who use their leisure time efficiently for activities such as relaxation, sports, health, and learning have developed and improved skills, with increased self-confidence, success, happiness, vitality in daily life, and healthy decision making (Ardahan, 2016). Given these positive relationships, the concept of free time evaluation has become a requirement of daily life (Tezcan, 1982), and the concept has reached people from all walks of life, whether it be business people, housewives, academics, people with disabilities, everyone aged 7 to 70; and continues to evolve with many possibilities and options (Koktas, 2014).

The university learning period is the most important period where behavior patterns acquired will continue for years. Participation in recreational activities helps to develop strong and resilient individuals (Agaoglu \& Eker, 2006) and it positively affects many fields of life, as shown in job satisfaction, life satisfaction, satisfaction with family life, and so on (Huang \& Carleton, 2003).

For these reasons, the concept of leisure time and recreational activities should be included and experienced as part of students' academic education. In this study, the aim was to evaluate the factors affecting free time participation according to the psychological, educational, social, relaxation, physiological and aesthetic dimensions of the university students using a short version of the scale of free time satisfaction according to sex, faculty, monthly income, evaluation of academic achievements and purposes of sports.

\section{Method}

\subsection{Research Group}

The research sample constituted 360 foreign students studying at Kocaeli University in the 2016-2017 academic year. The students were randomly chosen, with 257 being male (71.4\%) and 103 being female (28.6\%). The age range of this 
group is $63,1 \%$ in the age of $17-21,32,2 \%$ in the age of $22-26$ and $4,7 \%$ at the age of 27 and above.

\subsection{Data Collection Tools}

In this study, a personal information form consisting of fourteen questions developed by the researchers was used to collect demographic data on: age group, gender, monthly income, faculty, year in their course, level of academic achievement, welfare level, weekly leisure time, leisure time choices, preferred recreational fields, the frequency of participating in identified recreational fields.

To evaluate levels of satisfaction with leisure time, a valid and reliable Turkish version of the Leisure Satisfaction Scale (LSS) (Beard \& Ragheb, 1980), which consists of 39 questions, was used (Karli, Polat, Yilmaz, \& Kocak, 2008). The LSS has 6 subscales reflecting different domains of satisfaction with leisure time: psychological, education, social, relaxation, physiological, and aesthetic. In each subscale, higher scores indicate higher satisfaction levels.

\subsection{Data Collection}

The personal information form and LSS questionnaire was administered in face-to-face interviews with foreign students who voluntarily consented to participate in the questionnaire, at Kocaeli University Umuttepe Campus. The data collection was conducted over a period of 40 days.

\subsection{Data Analysis}

The collected data were analyzed in the IBM SPSS (Version 24) program. Frequency (f) and percentage (\%) values were calculated and tabulated. One-way analysis of variance (ANOVA) was conducted to determine the effects of faculty, monthly income, level of academic achievement, and sporting intention, on levels of satisfaction with leisure time. T-tests were conducted to determine the effect of gender on satisfaction levels with leisure time.

\section{Results}

Table 1. Distribution of students by age group

\begin{tabular}{lll}
\hline Age group & $\mathrm{n}$ & $\%$ \\
\hline $17-21$ & 227 & 63.1 \\
$22-26$ & 116 & 32.2 \\
27 and above & 17 & 4.7 \\
Total & 360 & 100
\end{tabular}

$63.1 \%$ of the students were in the 17-21 age group, $32.2 \%$ of the students were in the $22-26$ age group and $4.7 \%$ of the students were aged 27 or above.

Table 2. Distribution of students by gender

\begin{tabular}{lll}
\hline Gender & $\mathrm{n}$ & $\%$ \\
\hline Male & 257 & 71.4 \\
Female & 103 & 28.6 \\
Total & 360 & 100 \\
\hline
\end{tabular}

$71.4 \%$ of the students were male and $28.6 \%$ of the students were female.

Table 3. Distribution of students by income level

\begin{tabular}{lll}
\hline Income level (Turkish Lira) & $\mathrm{n}$ & $\%$ \\
\hline 1000 and below & 235 & 65.3 \\
$1001-2000$ & 96 & 26.7 \\
$2001-3000$ & 19 & 5.3 \\
3001 and above & 10 & 2.8 \\
Total & 360 & 100 \\
\hline
\end{tabular}

As monthly income, 65.3\% of the students received 1000 Turkish Lira or below; 26.7\% had 1001-2000 Turkish Lira, $5.3 \%$ had 2001-3000 Turkish Lira, and 2.8\% of the students received 3001 Turkish Lira or above. 
Table 4. Distribution of students across faculties

\begin{tabular}{lll}
\hline Faculty & $\mathrm{n}$ & $\%$ \\
\hline Engineering & 83 & 23.1 \\
Education Sciences & 11 & 3.1 \\
Social Sciences & 9 & 2.5 \\
Political Science & 22 & 6.1 \\
Health Sciences & 6 & 1.7 \\
Communication & 6 & 1.7 \\
Medicine & 23 & 6.4 \\
Arts and Sciences & 43 & 11.9 \\
Economics and Administrative Sciences & 31 & 8.6 \\
Other Faculties and Colleges & 126 & 35 \\
Total & 360 & 100 \\
\hline
\end{tabular}

$23.1 \%$ were studying at faculty of engineering, $3.1 \%$ of the students were studying at faculty of education sciences, $2.5 \%$ of the students were studying at faculty of social sciences, $6.1 \%$ of the students were studying at faculty of political science, $1.7 \%$ of the students were studying at faculty of health sciences, $1.7 \%$ of the students were studying at faculty of communication, $6.4 \%$ of the students were studying at faculty of medicine, $11.9 \%$ of the students were studying at faculty of arts and sciences, $8.6 \%$ of the students were studying at faculty of economics and administrative sciences and $35.0 \%$ of the students were studying at other faculties and colleges.

Table 5. Distribution of students across year in the course

\begin{tabular}{lll}
\hline Year & $\mathrm{n}$ & $\%$ \\
\hline 1st & 190 & 52.8 \\
2nd & 88 & 24.4 \\
3rd & 56 & 15.6 \\
4 th & 26 & 7.2 \\
Total & 360 & 100
\end{tabular}

$52.8 \%$ of the students were in their 1 st year, $24.4 \%$ of the students were in the 2nd year, $15.6 \%$ of the students were in the 3 rd year, and $7.2 \%$ of the students were in the 4 th year.

Table 6. Distribution of students across self-reported academic achievement levels

\begin{tabular}{lll}
\hline $\begin{array}{l}\text { Level of academic } \\
\text { achievement }\end{array}$ & $\mathrm{n}$ & $\%$ \\
\hline Low & 34 & 9.4 \\
Moderate & 196 & 54.4 \\
High & 130 & 36.1 \\
Total & 360 & 100
\end{tabular}

Students were asked "How do you evaluate your academic achievement status?" and in response, 9.4\% answered "low", $54.4 \%$ answered "moderate", and $36.1 \%$ of the students answered "high".

Table 7. Distribution of students across self-reported welfare levels

\begin{tabular}{lll}
\hline Variables & $\mathrm{n}$ & $\%$ \\
\hline Very bad & 12 & 3.3 \\
Bad & 20 & 5.6 \\
Normal & 151 & 41.9 \\
Well & 144 & 40.0 \\
Total & 360 & 100 \\
\hline
\end{tabular}


Students were asked, "When you think of the welfare level of people in the society, where do you see yourself?" and 3.3\% answered "very bad", 5.6\% answered "bad", 41.9\% answered "normal", and 40.0\% of the students answered "well".

Table 8. Distribution of students by weekly leisure time

\begin{tabular}{lll}
\hline Hours per week & $\mathrm{N}$ & $\%$ \\
\hline $1-5$ & 16 & 4.4 \\
$6-10$ & 32 & 8.9 \\
$11-15$ & 119 & 33.1 \\
16 and above & 193 & 53.6 \\
Total & 360 & 100
\end{tabular}

Students were asked, "How much leisure time do you have weekly?" and 4.4\% answered "1-5 hours", $8.9 \%$ answered " $6-10$ hours", $33.1 \%$ answered " $11-15$ hours", and 53.6\% of the students answered " 16 hours or above".

Table 9. Self-reported frequency of experienced difficulty with assessing leisure time

\begin{tabular}{lll}
\hline Frequency & $\mathrm{n}$ & $\%$ \\
\hline Always & 157 & 43.6 \\
Sometimes & 169 & 46.9 \\
Never & 34 & 9.4 \\
Total & 360 & 100
\end{tabular}

In reply to the question "How often do you have difficulty assessing your leisure time?", $43.6 \%$ of the students answered "always", $46.9 \%$ answered "sometimes", and 9.4\% answered "never".

Table 10. Self-reported preferred leisure activity

\begin{tabular}{lll}
\hline Preferred activities & $\mathrm{n}$ & $\%$ \\
\hline Home-based & 49 & 13.6 \\
Physical & 162 & 45.0 \\
Social & 104 & 28.9 \\
Cultural-artistic & 32 & 8.9 \\
Open field & 13 & 3.6 \\
Total & 360 & 100 \\
\hline
\end{tabular}

$13.6 \%$ of the student preferred home-based activities, $45.0 \%$ preferred physical activities, $28.9 \%$ preferred social activities, $8.9 \%$ preferred cultural-artistic activities, and 3.6\% of the students preferred open field activities.

Table 11. Student evaluation of the adequacy of the university's recreational areas

\begin{tabular}{lll}
\hline Variables & $\mathrm{n}$ & $\%$ \\
\hline Totally inadequate & 37 & 10.3 \\
Inadequate & 125 & 34.7 \\
Partly enough & 137 & 38.1 \\
Enough & 49 & 13.6 \\
Totally Enough & 12 & 3.3 \\
Total & 360 & 100
\end{tabular}

$10.3 \%$ of the students rated the university's recreational areas as being "totally inadequate", $34.7 \%$ rated these as being "inadequate", $38.1 \%$ rated these as being "partly enough", $13.6 \%$ rated these as being "enough", and 3.3\% rated these as being "totally enough". 
Table 12. Self-reported usage of university recreational areas

\begin{tabular}{lll}
\hline Hours per week & $\mathrm{n}$ & $\%$ \\
\hline $1-5$ & 205 & 56.9 \\
$6-10$ & 116 & 32.2 \\
$11-15$ & 34 & 9.4 \\
16 or above & 5 & 1.4 \\
Total & 360 & 100 \\
\hline
\end{tabular}

When asked about their weekly use of the university's recreational areas, $56.9 \%$ of the students indicated they used these recreational areas 1-5 hours per week, 32.2\% indicated 6-10 hours per week, 9.4\% indicated 11-15 hours per week, and $1.4 \%$ of the students indicated 16 hours or more per week.

Table 13. Location of recreational activities

\begin{tabular}{lll}
\hline Location & $\mathrm{n}$ & $\%$ \\
\hline On campus & 274 & 76.1 \\
Off campus & 79 & 21.9 \\
Other & 7 & 1.9 \\
Total & 360 & 100 \\
\hline
\end{tabular}

$76.1 \%$ of the students conducted their recreational activities on campus, $21.9 \%$ of the students off campus, and $1.9 \%$ of the students in "other" locations.

Table 14. Students' scores on the Leisure Satisfaction Scale (LSS) and its subscales

\begin{tabular}{llllll}
\hline LSS domain & $\mathrm{N}$ & Min. & Max. & Mean & SD \\
\hline Psychological & 360 & 20 & 39 & 26.92 & 2.87 \\
Education & 360 & 22 & 43 & 31.04 & 3.27 \\
Social & 360 & 16 & 40 & 30.43 & 3.44 \\
Relaxation & 360 & 8 & 20 & 14.36 & 2.27 \\
Physiological & 360 & 6 & 30 & 18.31 & 3.19 \\
Aesthetic & 360 & 6 & 20 & 11.03 & 2.41 \\
LSS total & 360 & 101 & 170 & 132.11 & 9.70
\end{tabular}

On average, students scored highest on the Education subscale and the lowest on the Aesthetic subscale.

Table 15. T-test comparisons of the LSS and its domains between genders

\begin{tabular}{|c|c|c|c|c|c|c|}
\hline LSS domains & Gender & $\mathrm{N}$ & Mean & SD & $\mathrm{t}$ & $\mathrm{p}$ \\
\hline \multirow{2}{*}{ Psyschological } & Male & 257 & 27.10 & 2.93 & \multirow{2}{*}{1.953} & \multirow{2}{*}{.052} \\
\hline & Female & 103 & 26.47 & 2.69 & & \\
\hline \multirow{2}{*}{ Education } & Male & 257 & 31.10 & 3.29 & \multirow{2}{*}{.587} & \multirow{2}{*}{.558} \\
\hline & Female & 103 & 30.88 & 3.21 & & \\
\hline \multirow{2}{*}{ Social } & Male & 257 & 30.36 & 3.50 & \multirow{2}{*}{-.661} & \multirow{2}{*}{.510} \\
\hline & Female & 103 & 30.62 & 3.31 & & \\
\hline \multirow{2}{*}{ Relaxation } & Male & 257 & 14.32 & 2.26 & \multirow{2}{*}{-.495} & \multirow{2}{*}{.621} \\
\hline & Female & 103 & 14.45 & 2.32 & & \\
\hline \multirow{2}{*}{ Physiological } & Male & 257 & 18.38 & 3.32 & \multirow{2}{*}{.686} & \multirow{2}{*}{.494} \\
\hline & Female & 103 & 18.14 & 2.85 & & \\
\hline \multirow{2}{*}{ Aesthetic } & Male & 257 & 11.05 & 2.42 & \multirow{2}{*}{.195} & \multirow{2}{*}{.846} \\
\hline & Female & 103 & 11.00 & 2.38 & & \\
\hline \multirow{2}{*}{ Leisure Satisfaction Scale } & Male & 257 & 132.33 & 10.14 & \multirow{2}{*}{.716} & \multirow{2}{*}{.475} \\
\hline & Female & 103 & 131.58 & 8.51 & & \\
\hline
\end{tabular}

$\mathrm{p}>0.005$

Comparisons between the genders found no significant difference in the level of satisfaction with free time ( $\mathrm{p}>0.05$ ). 
Table 16. T-test comparisons of LSS scores by faculties

\begin{tabular}{|c|c|c|c|c|c|c|}
\hline Subscale & Faculty & $\mathrm{N}$ & Mean & SD & $\mathrm{t}$ & $\mathrm{p}$ \\
\hline \multirow{9}{*}{ Psychological } & Engineering & 83 & 26.67 & 3.11 & \multirow{9}{*}{2.507} & \multirow{9}{*}{$.009 *$} \\
\hline & Educational Sciences & 11 & 28.81 & 2.99 & & \\
\hline & Social Sciences & 9 & 28.55 & 2.74 & & \\
\hline & Political Science & 22 & 27.40 & 3.96 & & \\
\hline & Health Sciences & 6 & 25.50 & 1.76 & & \\
\hline & Communication & 6 & 29.66 & 3.14 & & \\
\hline & Medicine & 23 & 27.13 & 2.52 & & \\
\hline & Arts and Sciences & 43 & 26.11 & 2.55 & & \\
\hline & Economics and Administrative Sciences & 31 & 26.19 & 2.28 & & \\
\hline \multirow{13}{*}{ Education } & Other Faculties and Colleges & 126 & 27.07 & 2.64 & \multirow{13}{*}{.696} & \\
\hline & Total & 360 & 26.92 & 2.87 & & \\
\hline & Engineering & 83 & 31.28 & 3.65 & & \\
\hline & Educational Sciences & 11 & 31.36 & 4.29 & & \\
\hline & Social Sciences & 9 & 30.11 & 1.36 & & \\
\hline & Political Science & 22 & 30.04 & 3.24 & & \\
\hline & Health Sciences & 6 & 29.83 & 4.11 & & \\
\hline & Communication & 6 & 32.33 & 3.55 & & .712 \\
\hline & Medicine & 23 & 31.08 & 3.32 & & \\
\hline & Arts and Sciences & 43 & 31.51 & 3.79 & & \\
\hline & Economics and Administrative Sciences & 31 & 31.16 & 2.13 & & \\
\hline & Other Faculties and Colleges & 126 & 30.88 & 2.99 & & \\
\hline & Total & 360 & 31.04 & 3.27 & & \\
\hline & Engineering & 83 & 30.89 & 3.47 & & \\
\hline & Educational Sciences & 11 & 32.81 & 3.57 & & \\
\hline & Social Sciences & 9 & 30.77 & 2.22 & & \\
\hline & Political Science & 22 & 29.00 & 4.16 & & \\
\hline & Health Sciences & 6 & 31.66 & 5.46 & & \\
\hline Social & Communication & 6 & 29.66 & 1.86 & 1.813 & .062 \\
\hline & Medicine & 23 & 31.21 & 2.81 & & \\
\hline & Arts and Sciences & 43 & 30.44 & 3.13 & & \\
\hline & Economics and Administrative Sciences & 31 & 30.77 & 2.59 & & \\
\hline & Other Faculties and Colleges & 126 & 29.90 & 3.57 & & \\
\hline & Total & 360 & 30.43 & 3.44 & & \\
\hline & Faculty of Engineering & 83 & 14.40 & 2.38 & & \\
\hline & Educational Sciences & 11 & 14.63 & 1.68 & & \\
\hline & Social Sciences & 9 & 14.11 & 1.36 & & \\
\hline & Political Science & 22 & 13.86 & 2.49 & & \\
\hline & Health Sciences & 6 & 15.33 & 3.50 & & \\
\hline Relaxation & Communication & 6 & 15.00 & 2.52 & 1.443 & .168 \\
\hline & Medicine & 23 & 13.73 & 2.07 & & \\
\hline & Arts and Sciences & 43 & 15.02 & 2.05 & & \\
\hline & Economics and Administrative Sciences & 31 & 15.00 & 2.03 & & \\
\hline & Other Faculties and Colleges & 126 & 14.06 & 2.31 & & \\
\hline & Total & 360 & 14.36 & 2.27 & & \\
\hline & Engineering & 83 & 18.22 & 2.73 & & \\
\hline & Educational Sciences & 11 & 18.09 & 3.38 & & \\
\hline & Social Sciences & 9 & 18.66 & 2.82 & & \\
\hline & Political Science & 22 & 18.18 & 3.15 & & \\
\hline & Health Sciences & 6 & 19.50 & 5.08 & & \\
\hline Physiological & Communication & 6 & 18.16 & 4.40 & .708 & .701 \\
\hline & Medicine & 23 & 18.91 & 3.78 & & \\
\hline & Arts and Sciences & 43 & 19.00 & 3.10 & & \\
\hline & Economics and Administrative Sciences & 31 & 18.70 & 3.01 & & \\
\hline & Other Faculties and Colleges & 126 & 17.90 & 3.32 & & \\
\hline & Total & 360 & 18.31 & 3.19 & & \\
\hline & Engineering & 83 & 11.15 & 2.56 & & \\
\hline & Educational Sciences & 11 & 12.72 & 3.34 & & \\
\hline & Social Sciences & 9 & 11.00 & 1.73 & & \\
\hline & Political Science & 22 & 11.13 & 2.69 & & \\
\hline & Health Sciences & 6 & 11.83 & 1.60 & & \\
\hline Aesthetic & Communication & 6 & 11.83 & 3.60 & 1.049 & .401 \\
\hline & Medicine & 23 & 10.47 & 1.95 & & \\
\hline & Arts and Sciences & 43 & 11.06 & 2.72 & & \\
\hline & Economics and Administrative Sciences & 31 & 10.61 & 1.78 & & \\
\hline & Other Faculties and Colleges & 126 & 10.92 & 2.26 & & \\
\hline & Total & 360 & 11.03 & 2.41 & & \\
\hline & Engineering & 83 & 132.65 & 10.31 & & \\
\hline & Educational Sciences & 11 & 138.45 & 13.00 & & \\
\hline & Social Sciences & 9 & 133.22 & 5.11 & & \\
\hline & Political Science & 22 & 129.63 & 12.25 & & \\
\hline & Health Sciences & 6 & 133.66 & 12.53 & & \\
\hline Leisure Satisfaction Scale & Communication & 6 & 136.66 & 15.44 & 1.231 & .275 \\
\hline & Medicine & 23 & 132.56 & 10.03 & & \\
\hline & Arts and Sciences & 43 & 133.16 & 9.60 & & \\
\hline & Economics and Administrative Sciences & 31 & 132.45 & 6.32 & & \\
\hline & Other Faculties and Colleges & 126 & 130.76 & 8.80 & & \\
\hline & Total & 360 & 132.11 & 9.70 & & \\
\hline
\end{tabular}


When the findings were examined, there was a significant difference only in the Psychological subscale. In the other subscales, no significant difference was found.

Table 17. ANOVA of the LSS scores by monthly income

\begin{tabular}{|c|c|c|c|c|c|c|}
\hline LSS & $\begin{array}{l}\text { Monthly income } \\
\text { (Turkish Lira) }\end{array}$ & $\mathrm{N}$ & Mean & SD & $\mathrm{f}$ & $\mathrm{p}$ \\
\hline \multirow{5}{*}{ Psychological } & 1000 and below & 235 & 27.05 & 2.76 & \multirow{5}{*}{.488} & \multirow{5}{*}{.691} \\
\hline & $1001-2000$ & 96 & 26.64 & 3.35 & & \\
\hline & $2001-3000$ & 19 & 26.73 & 1.59 & & \\
\hline & 3001 and above & 10 & 26.9 & 2.42 & & \\
\hline & Total & 360 & 26.92 & 2.87 & & \\
\hline \multirow{5}{*}{ Education } & 1000 and below & 235 & 31.08 & 3.42 & \multirow{5}{*}{.132} & \multirow{5}{*}{.941} \\
\hline & $1001-2000$ & 96 & 31.02 & 2.99 & & \\
\hline & $2001-3000$ & 19 & 30.84 & 2.79 & & \\
\hline & 3001 and above & 10 & 30.5 & 3.37 & & \\
\hline & Total & 360 & 31.04 & 3.27 & & \\
\hline \multirow{5}{*}{ Social } & 1000 and below & 235 & 30.44 & 3.46 & \multirow{5}{*}{.514} & \multirow{5}{*}{.673} \\
\hline & $1001-2000$ & 96 & 30.62 & 3.27 & & \\
\hline & $2001-3000$ & 19 & 29.78 & 4.41 & & \\
\hline & 3001 and above & 10 & 29.6 & 2.91 & & \\
\hline & Total & 360 & 30.43 & 3.44 & & \\
\hline \multirow{5}{*}{ Relaxation } & 1000 and below & 235 & 14.44 & 2.29 & \multirow{5}{*}{2.832} & \multirow{5}{*}{$.038^{*}$} \\
\hline & $1001-2000$ & 96 & 13.90 & 2.26 & & \\
\hline & $2001-3000$ & 19 & 14.94 & 1.77 & & \\
\hline & 3001 and above & 10 & 15.60 & 2.11 & & \\
\hline & Total & 360 & 14.36 & 2.27 & & \\
\hline \multirow{5}{*}{ Physiological } & 1000 and below & 235 & 18.50 & 3.39 & \multirow{5}{*}{1.392} & \multirow{5}{*}{.245} \\
\hline & $1001-2000$ & 96 & 17.79 & 2.59 & & \\
\hline & $2001-3000$ & 19 & 18.21 & 3.72 & & \\
\hline & 3001 and above & 10 & 19.20 & 2.14 & & \\
\hline & Total & 360 & 18.31 & 3.19 & & \\
\hline \multirow{5}{*}{ Aesthetic } & 1000 and below & 235 & 11.11 & 2.39 & \multirow{5}{*}{.668} & \multirow{5}{*}{.572} \\
\hline & $1001-2000$ & 96 & 11.03 & 2.4 & & \\
\hline & $2001-3000$ & 19 & 10.31 & 2.26 & & \\
\hline & 3001 and above & 10 & 10.8 & 3.25 & & \\
\hline & Total & 360 & 11.03 & 2.41 & & \\
\hline \multirow{5}{*}{$\begin{array}{l}\text { Leisure } \\
\text { Satisfaction } \\
\text { Scale }\end{array}$} & 1000 and below & 235 & 132.65 & 10.31 & \multirow{5}{*}{.762} & \multirow{5}{*}{.516} \\
\hline & $1001-2000$ & 96 & 131.02 & 8.06 & & \\
\hline & $2001-3000$ & 19 & 130.84 & 9.55 & & \\
\hline & 3001 and above & 10 & 132.60 & 9.74 & & \\
\hline & Total & 360 & 132.11 & 9.70 & & \\
\hline
\end{tabular}

$\mathrm{p}<0.05$

There was a significant difference in the relaxation subscale according to the students' monthly income. 
Table 18. ANOVA of the LSS scores by levels of academic achievement

\begin{tabular}{|c|c|c|c|c|c|c|}
\hline LSS & Academic achievement & $\mathrm{N}$ & Mean & SD & $\mathrm{f}$ & $\mathrm{p}$ \\
\hline \multirow{4}{*}{ Psychological } & Low & 34 & 26.26 & 2.20 & \multirow{4}{*}{1.852} & \multirow{4}{*}{.158} \\
\hline & Moderate & 196 & 27.16 & 2.98 & & \\
\hline & High & 130 & 26.73 & 2.83 & & \\
\hline & Total & 360 & 26.92 & 2.87 & & \\
\hline \multirow{4}{*}{ Education } & Low & 34 & 29.94 & 2.88 & \multirow{4}{*}{2.217} & \multirow{4}{*}{.110} \\
\hline & Moderate & 196 & 31.21 & 3.34 & & \\
\hline & High & 130 & 31.06 & 3.21 & & \\
\hline & Total & 360 & 31.04 & 3.27 & & \\
\hline \multirow{4}{*}{ Social } & Low & 34 & 29.26 & 3.57 & \multirow{4}{*}{2.960} & \multirow{4}{*}{.053} \\
\hline & Moderate & 196 & 30.75 & 3.48 & & \\
\hline & High & 130 & 30.26 & 3.30 & & \\
\hline & Total & 360 & 30.43 & 3.44 & & \\
\hline \multirow{4}{*}{ Relaxation } & Low & 34 & 15.11 & 2.08 & \multirow{4}{*}{2.155} & \multirow{4}{*}{.117} \\
\hline & Moderate & 196 & 14.32 & 2.33 & & \\
\hline & High & 130 & 14.22 & 2.22 & & \\
\hline & Total & 360 & 14.36 & 2.27 & & \\
\hline \multirow{4}{*}{ Physiological } & Low & 34 & 17.79 & 2.43 & \multirow{4}{*}{.610} & \multirow{4}{*}{.544} \\
\hline & Moderate & 196 & 18.43 & 3.19 & & \\
\hline & High & 130 & 18.26 & 3.37 & & \\
\hline & Total & 360 & 18.31 & 3.19 & & \\
\hline \multirow{4}{*}{ Aesthetic } & Low & 34 & 10.73 & 2.24 & \multirow{4}{*}{.409} & \multirow{4}{*}{.665} \\
\hline & Moderate & 196 & 11.12 & 2.44 & & \\
\hline & High & 130 & 10.99 & 2.42 & & \\
\hline & Total & 360 & 11.03 & 2.41 & & \\
\hline \multirow{4}{*}{$\begin{array}{l}\text { Leisure } \\
\text { Satisfaction } \\
\text { Scale }\end{array}$} & Low & 34 & 129.11 & 6.42 & \multirow{4}{*}{2.693} & \multirow{4}{*}{.069} \\
\hline & Moderate & 196 & 133.01 & 10.05 & & \\
\hline & High & 130 & 131.56 & 9.73 & & \\
\hline & Total & 360 & 132.11 & 9.70 & & \\
\hline
\end{tabular}

There was no significant difference in Leisure Satisfaction Scores by levels of academic achievement.

\section{Results, Conclusions and Recommendations}

As a result of our statistical analyses, students scored higher on the Education subscale of the LSS on average compared to the other LSS subscales. Additionally, it was observed that on average the Aesthetic subscale was scored the lowest.

In a study conducted with 173 male and 223 female participants in the province of Antalya (Lapa, 2013), it was found that the Education subscale was scored the highest score, as in our study, but the Social subscale was scored the lowest. When we examined the effect of gender in our study, there was no significant difference between the genders on levels of satisfaction with leisure time. This result is similar to the findings of Misra and McKean (2000). A similar result was obtained by Lu and Hu (2005) on Chinese university students. Siegenthaller and O'Dell (2000), and Di Bona (2000) also found no significant difference between genders on the levels of satisfaction with leisure time. Griffin and McKenna (1998) and Boley (2001) found similar results in their studies on elderly individuals. Berg, Trost, Schneider and Allison (2001) found that there was no significant difference in the level of satisfaction with leisure time between the male and female subjects in their study of couples. Similarly, the results of the work by Ardahan and Lapa (2010) indicate that scores on the LSS and its subscales did not differ according to sex. Similar results were obtained in the literature by Gokce (2008), Ngai (2005), and Kabanoff (1982). Spiers and Walker (2009) concluded that gender had no 
significant effect on levels of satisfaction with free time. However, Brown and Frankel (1993) reported that males scored higher levels of satisfaction with their free time.

When we analyzed the subscales of the LSS according to monthly income variables, we found that scores for Relaxation were higher than for the other subscales. These findings are similar to Russell's finding (1987) that levels of satisfaction with leisure time are associated with income. Bonke, Deding, \& Lausten (2007) also found a positive relationship between income and satisfaction with leisure time: as incomes rise, participants' level of satisfaction with their leisure time also increases. However, in a study by Mancini (1978), the level of satisfaction with leisure time was not affected by income. Ngai (2005), in a study of 993 participants living in the Macao region of the People's Republic of China, reported that the level of satisfaction with free time did not differ according to the income. The results of the studies performed by Mancini (1978) and Ngai (2005) may differ from those in our study because of different sample characteristics in the studies.

It was determined that there was no significant difference between the genders on their level satisfaction with leisure time. Similarly, there was no significant difference between the levels of academic achievement on levels of satisfaction with leisure time.

With regard to the faculty of the student, only the Psychological subscale of the LSS was statistically significant. Levels of psychological satisfaction of these individuals is high.

In relation to the monthly income level, a statistically significant difference was also found.

Given these findings, the following are our recommendations for researchers:

1- Further research should be conducted to look at the different factors that affect differences in levels of satisfaction in university students with leisure time.

2- Qualitative observation-based studies may allow consideration of the issue from different dimensions.

3- The same study can be conducted in different universities to obtain more generalizable results.

The following are our recommendations for students:

1- Creating panels in each faculty can increase student awareness of the recreational opportunities and activities at the university.

2- Preparing English announcements for foreign students can help them understand and make them more comfortable with activities.

3- Providing joint participation of all faculties through organizations can allow for socialization of foreign students.

4- Offering elective courses at each faculty, for different recreational activities that students may be interested in, can promote student participation.

5- Holding weekly outdoor activities for different countries, under the name of National Recreation, with the help of foreign students, is also another way of promoting student participation.

6- Creating English-speaking only areas in the faculty (e.g., cafés, classrooms, a few green spaces and so on) can generate opportunities for foreign students to speak English with others.

\section{References}

Agaoglu, Y. S., \& Eker, H. (2006). The Investigation of Health, Culture and Sports Institutions of Universities in terms of Functionality in Turkey. Spormetre Journal of Physical Education and Sports Sciences, 4(4), 131-134.

Ardahan, F. (2016). Recreation from Every Aspect, Detay Publishment, Ankara.

Ardahan, F., \& Lapa, T. (2010). An Examination of Leisure Satisfaction Level of University Students with regard to Gender and Income. Hacettepe Journal of Sport Sciences, 21(4), 129-136.

Ayyildiz, T. (2015). The Investigation of Leisure Satisfaction Levels of Individuals that Attend Dancing Activities (Unpublished master's thesis). Gazi University, Ankara, Turkey.

Beard, J. G., \& Ragheb, M. G. (1980). Measuring leisure satisfaction. Journal of Leisure Research, 12(1), 20-33. https://doi.org/10.1080/00222216.1980.11969416

Berg, E., Trost, M., Schneider, I. E., \& Allison, M. T. (2001). Dyadic exploration of the relationship of leisure satisfaction, leisure time, and gender to relationship satisfaction. Leisure Sciences, 23, 35-46. https://doi.org/10.1080/01490400150502234

Boley, B. J. (2001). Life Satisfaction, Leisure Satisfaction, and Leisure Participation Among Publicly Housed Older Adults (Unpublished Doctoral Dissertation). Capella University, Minneapolis, USA. 
Bonke, J., Deding, M., \& Lausten, M. (2009). Time and Money: A simultaneous analysis of men's and women's

Brown, A. B., \& Frankel, B. G. (1993). Activity through years: leisure, leisure satisfaction, and life satisfaction. Sociology of Sports Journal, 10, 1-17. https://doi.org/10.1123/ssj.10.1.1

Di Bona, L. (2000). What are the benefits of leisure? An exploration using the leisure satisfaction scale. British Journal of Occupational Therapy, 63(2), 50-58. https://doi.org/10.1177/030802260006300202

domain satisfactions. Journal Happiness Stud, 10, 113-131. https://doi.org/10.1007/s10902-007-9064-3

Gokce, H. (2008). Examining of the Leisure Satisfaction with the Relation Between Life Satisfaction and Sociodemographic Variables (Unpublishled Master's Thesis). Pamukkale University, Denizli, Turkey.

Griffin, J., \& McKenna, K. (1998). Influences on leisure and life satisfaction of elderly people. Physical \& Occupational Therapy in Geriatrics, 15 (4), 1-16. https://doi.org/10.1080/J148V15n04_01

Huang, C. Y., \& Carleton, B. (2003). The relationships among leisure participation, leisure satisfaction and life satisfaction of college students in Taiwan. Journal of Exercise Science and Fitness, 1(2), 129-132.

Kabanoff, B. (1982). Occupational and sex differences in leisure needs and leisure satisfaction. Journal of Occupational Behavior, 3, 233-245. https://doi.org/10.1002/job.4030030304

Karli, U., Polat, E., Yilmaz, B., \& Kocak, S. (2008). Reliability and Validity Study of Leisure Satisfaction Scale (LSS-Long Version). Hacettepe Journal of Sports Sciences, 19(2), 80-91. https://doi.org/10.1016/j.sbspro.2013.10.153

Koktas, S. (2014). Recreation-Efficiently Usage of Leisure Time, Nobel Press, Ankara.

Lapa, T. Y. (2013). Life satisfaction, leisure satisfaction and perceived freedom of park recreation participants. Procedia-Social and Behavioral Sciences, 93, 1985-1993.

Lu, L., \& Hu, C. H. (2005). Personality, leisure experiences, and happiness. Journal of Happiness Studies, 6(3), 325-342. https://doi.org/10.1007/s10902-005-8628-3

Mancini, J. A. (1978). Leisure Satisfaction and Psychologic Well-being in Old Age: Effects of Health and Income. Journal of the American Geriatrics Society, 26(12), 550-552. https://doi.org/10.1111/j.1532-5415.1978.tb05038.x

Misra, R., \& McKean, M. (2000). College students academic stress and its relation to their anxiety, time management, and leisure satisfaction. American Journal of Health Studies, 16(1), 41-51.

Ngai, V. T. (2005). Leisure satisfaction and quality of life in Macao, China. Leisure Studies, 24(2), 195-207. https://doi.org/10.1080/02614360412331313502

Roberts, K. (2006). Leisure in contemporary society (2nd press). Wallingford, UK: Cabi. https://doi.org/10.1079/9781845930691.0000

Russell, R. V. (1987). The importance of recreation satisfaction and activity participation to the life satisfaction of age-segregated retirees. Journal of Leisure Research, 19(4), 273-283. https://doi.org/10.1080/00222216.1987.11969698

Siegenthaller, K. L., \& O’Dell, I. (2000). Leisure attitude, leisure satisfaction, and perceived freedom in leisure within family dyads. Leisure Sciences, 22, 281-295. https://doi.org/10.1080/01490409950202302

Spiers, A., \& Walker, G. J. (2009). The Effects of Ethnicity and Leisure Satisfaction on Happiness. Peacefulness and Quality of Life Leisure Sciences, 31, 84-99. https://doi.org/10.1080/01490400802558277

Tezcan, M. (1982). Sociology of Leisure Time. Ankara University Faculty of Education Publishment.

Tezcan, M. (1994). Sociology of Efficiently Usage of Leisure Time. Ankara: Atilla Press.

\section{Copyrights}

Copyright for this article is retained by the author(s), with first publication rights granted to the journal.

This is an open-access article distributed under the terms and conditions of the Creative Commons Attribution license which permits unrestricted use, distribution, and reproduction in any medium, provided the original work is properly cited. 